\title{
Model Pelatihan, Pembinaan dan Pendampingan Usaha Sala Lauak di Ulakan Pariaman Sumatera Barat
}

\author{
Desi Handayani, \\ Jurusan Akuntansi, Politeknik Negeri Padang \\ Surfa Yondri \\ Jurusan Elektro, Politeknik Negeri Padang
}

\begin{abstract}
This article discusses the model of training, development and accompaniment of small business of sala Lauak in Ulakan. The purposes of this project are to increase and improve: 1) Understanding of partner to business planning and management by transferring knowledge to improve their ability in accounting and simple book keeping. 2) Their ability to do process traditional food hygienically, using supported tools of production (Frying and packing) 3) The value added of traditional food and their income through product diversification, developing new recipes ,and variety of product sold. 4) Their Services in sales by re lay out stall and sales method in order to comfort their buyer; 5) their product quality by supporting partner get legality of production. 6) Finding the right model for training by sharing method and discussion also direct practice, 7) Finding model of development and empower the community to be role model of conceptual, hygienic and competitive development of region
\end{abstract}

Keywords : competitive, hygienic, model, training, traditional food, re layout, sala lauak, simple accounting.

\section{PENDAHULUAN}

Nagari Ulakan berada di Pesisir Pantai Kabupaten Padang Pariaman Sumatera Barat. Daerah ini terkenal dengan kunjungan bersyafamya pengikut ulama besar Syatariyah Syeikh Burhanuddin di Ulakan, kemakam Syeikh Burhanuddin.Luas wilayah Nagari Ulakan $38,85 \mathrm{Km}$ (termasuk sebuah pulau kecil yaitu Pulau Pieh seluas 3 $\mathrm{Ha}$ ),Nagari Ulakan berpenduduk 18.369 jiwa. Mata pencaharian masyarakat umumnya nelayan dan bertani dan sebagian lain berdagang.

Pariaman terkenal dengan kuliner khas tradisional "Sala Lauak" berupa gorengan yang rasanya lezat dan gurih. Adonannya adalah tepung beras yang disangrai, bumbu dapur dan aneka daundaunan serta potongan kecil-kecil ikan asin yang lalu dibentuk bulat-bulat sebesar bola ping-pong kemudian digoreng. Keberadaan Makam Syekh Burhanuddin di wilayah Ulakan memotivasi ibu-ibu rumah tangga berjualan Sala Lauak di sepanjang jalan Raya Ulakan Tapakis menuju Makam Syekh Burhanuddin. Ada sekitar 35 pedagang sala lauak di sepanjang jalan Ulakan. Mitra terpilih dalam kegiatan ini adalah 2 pedagang sekaligus pembuat sala lauak, yaitu usaha Sala Kitik dan Sala Helmi.

Home Industry Sala Lauak ini dalam pengembangannya masih memerlukan pembinaan dan pendampingan secara intensif agar memiliki daya saing, produk yang dihasilkan berkualitas baik dan dapat memenuhi permintaan pasar. Upaya meningkatkan kualitas dan pendapatan usaha kecil menengah harus dilakukan dengan meningkatkan kualitas Sumber Daya Manusianya (pedagang) untuk menerapkan pengolahan pangan yang aman, kemasan yang baik, pemasaran dan pelayanan baik. Target dari kegiatan ini pada jangka panjang dapat meningkatkan kualitas, kuantitas serta menjadi Pilot Project untuk Home Industry yang higienis, efisien dan berdaya saing. Juga diharapkan dapat memperluas produksi, jangkauan pemasaran serta dapat mendukung pengembangan wisata di wilayah Ulakan dan sekitarnya sehingga 
dapat dijadikan sebagai produk unggulan daerah.

Makanan Tradisional merupakan kelompok makanan ringan yang sangat beranekaragam jenisnya, dapat berbentuk makanan kering, makanan basah, bubur ataupun minuman. Kelompok makanan tradisional berkembang secara tradisional, dan dijual di pasar-pasar tradisional. Seiring perkembangan zaman, makanan tradisional berkembang mempertahankan eksistensinya sebagai makanan yang menarik, memenuhi selera masyarakat dan berdaya saing. Kita dapat menemukan kehadiran makanan tradisional di toko-toko swalayan, hotel berbintang, hidangan dalam rapat para pejabat, acara kenegaraan serta pada acara pertemuan diberbagai golongan masyarakat. Meskipun statusnya hanya makanan selingan, tetapi dapat memberikan sumbangan terhadap pemenuhan gizi sehari hari. Kenyataan ini menunjukkan bahwa kelompok makanan tradisional mempunyai potensi untuk dapat dikembangkan. Meskipun sebagian besar produksinya masih secara tradisional namun terbukti telah mampu untuk mendampingi makanan ringan lain yang dihasilkan dengan teknologi modern. Usaha pengembangan makanan sederhana penting, karena dengan teknologi makanan tradisional dapat menjadi kekuatan ekonomi dan pemberdayaan masyarakat yang berarti.

Di dalam pengembangan makanan tradisional, jika dilaksanakan secara sungguh-sungguh dan didukung oleh ilmu pengetahuan dan teknologi yang tepat akan tercipta produk yang menarik, dengan penampakan dan kemasan yang rapi, nilai gizinya telah terancang dan lebih higienis. Dengan demikian terciptalah keseimbangan antara kualitas yang telah dicapai oleh produsen dan preferensi konsumen. Keseimbangan antara kualitas dan kesukaan yang menyangkut kriteria kesukaan secara luas, seperti: kenampakan, citarasa, tekstur, serta keamanan.

Penggalian mengenai berbagai aspek tentang makanan tradisional hingga sekarang masih langka, misalnya peranannya dalam mendukung perekonomian rakyat, sumbangannya terhadap pengembangan produk baru dan sebagainya. Oleh karena itu berbagai kegiatan dan strategi penggalian dan pengembangan perlu dilakukan agar berbagai makanan tradisional mampu berkembang dan tidak punah. Dengan demikian kita akan dapat mengambil langkah- langkah yang tepat dalam usaha untuk melestarikan dan mengembangkan golongan makanan tradisional.

Makanan tradisional banyak dibuat dengan komponen utama karbohidrat. Antara karbohidrat satu dengan yang lainnya sifatnya berbeda. Sebagai contoh karbohidrat dari aneka umbi-umbian adalah: singkong, ubi rambat, garut, dan sejenisnya. Juga buah-buahan yang dapat digunakan sebagai sumber karbohidrat, seperti: pisang, sukun dan labu kuning.

\section{Keamanan Pangan}

Makanan harus mengandung zat gizi yang terdiri dari lemak, protein, karbohidrat, mineral dan vitamin. Makanan juga harus baik dan aman dikonsumsi. Jika ketiga unsur (bergizi, baik dan aman) terpenuhi, maka baru dapat disebut dengan Makanan Sehat.

Keamanan pangan merupakan hal yang penting dari ilmu sanitasi. Keamanan pangan harus diperhatikan oleh produsen pangan maupun konsumen. Kontaminasi makanan yang disebabkan kontaminasi mikroba berperan besar dalam kejadian penyakit-penyakit bawaan makanan atau keracunan makanan. Sumber penyakit yang mungkin mencemari makanan dapat terjadi selama proses produksi yang dimulai dari pemeliharaan, pemanenan, penyimpanan, penyembelihan, pembersihan atau pencucian, persiapan makanan atau pengolahan, serta penyajian.

Pemakaian bahan tambahan makanan sintetis memang menjanjikan banyak keuntungan, karena penggunaannya praktis dan mudah diperoleh. Namun di balik keuntungan tersebut karena bahan sintetis merupakan bahan kimia, maka jika salah penggunaannya akan membahayakan. Penggunaan bahan-bahan kimia dalam produksi makanan juga menambah daftar resiko kontaminasi oleh bahan-bahan kimia. Zat-zat aditif buatan dicampur dalam suplay makanan untuk beberapa alasan. Beberapa zat aditif buatan jika ditambahkan dalam produk makanan dalam jumlah berlebihan akan menyebabkan keracunan makanan. Nitrit dan Niacin adalah contoh zat aditif yang beracun dalam jumlah yang berlebihan. 
Prinsip dalam menyelenggarakan makanan adalah untuk menyediakan makanan berkualitas baik, aman bagi kesehatan konsumen,kemungkinan resiko penularan penyakit dan gangguan kesehatan kecil serta terwujudnya perilaku kerja yang sehat dan benar dalam menangani makanan. Tujuan tersebut dapat dicapai jika semua pihak yang terkait turut bertanggungjawab dalam menciptakan sanitasi dan hygiene makanan mulai dari pengadaan bahan makanan, proses penyimpanan, pengolahan hingga sampai makanan siap untuk disantap. Bahan baku yang akan digunakan untuk pengolahan makanan, harus diusahakan bebas dari cemaran. Hal yang perlu diperhatikan dalam proses pengolahan makanan antara lain adalah sanitasi tempat pengolahan, hygiene tenaga pengolah serta hygiene dan sanitasi cara-cara pengolahan.

Tempat pengolahan yang baik adalah tempat yang kebersihannya terjaga, ada persediaan air bersih, tersedia tempat sampah, tersedia tempat pembuangan air limbah, pertukaran udara selalu segar, penerangan cukup, tersedia bak pencuci tangan, terhindar dari debu dan adanya serangga atau tikus. Bangunan juga didesain agar mudah dibersihkan. Ruangan diatur sedemikian rupa agar higienitasi tempat pengolahan dapat terlaksana. Yaitu dengan cara mengatur alur kerja mulai dari persiapan bahan baku hingga makanan siap disajikan. Lantai, dinding dan langit-langit ruang pengolahan tersebut dari bahan baku yang mudah dibersihkan.

\section{Pemberdayaan masyarakat}

Hasil pertanian dan budidaya pangan suatu daerah merupakan suatu aset ekonomi, budaya dan kesehatan masyarakat. Oleh karena itu sangat tepat apabila sasaran pembangunan bidang pangan di Indonesia diantaranya adalah; terwujudnya ketahanan pangan rumah tangga, terwujudnya diversifikasi pangan serta terjamin keamanan pangan. Keberadaan industri pengolahan makanan hasil pertanian di Indonesia yang paling besar adalah industri rumah tangga, kemudian industri kecil dan industri menengah dan besar.

Pemuda dan ibu rumah tangga mempunyai penting dalam pembangunan diberbagai sektor. Kedua unsur ini dapat menentukan arah kemajuan bangsa ke depan, sehingga berbagai kebijakan harus dapat menunjang pemberdayaan pemuda dan masyarakat agar lebih produktif dalam berbagai bidang. Upaya untuk memberdayakan masyarakat dapat di lakukan melalui pembinaan yang intensif dan terstruktur sehingga berkelanjutan. Pemberdayaan masyarakat ini bisa di lakukan melalui home industry yang mengolah makanan tradisional yang di percaya bisa meningkatkan potensi ekonomi masyarakat.

\section{Pentingnya Manajemen Keuangan}

Salah satu kelemahan usaha kecil di Indonesia ialah tidak dikuasainya dan dipraktekkannya pencatatan keuangan yang memadai. Usaha kecil umumnya belum memiliki pengetahuan dan kemampuan dalam mengelola catatan akuntansi secara teratur dan disiplin pembukuannya, baik dalam bentuk harian, mingguan, bulanan, ataupun tahunan. Banyak diantara mereka yang belum memahami pentingnya pencatatan dan pembukuan bagi kelangsungan usaha. Pencatatan akuntansi yang tidak memadai pada UMKM disebabkan juga anggapan hanya membuang-buang waktu dan biaya.

Jenjang pendidikan terakhir dan latar belakang pendidikan tidak berpengaruh signifikan terhadap persepsi pengusaha UMKM terhadap pentingnya pembukuan dan pelaporan keuangan bagi usahanya (Rudiantoro \& Siregar, 2011).

Adanya pengawasan, keinginan berprestasi dan pengetahuan akuntansi memberikan pengaruh positif terhadap penggunaan informasi akuntansi dalam keputusan investasi (Suhairi, dkk, 2004).

$$
\text { Rudiantoro \& Siregar (2011) }
$$

menyatakan bahwa pemberian informasi dan sosialisasi serta jenjang pendidikan terakhir pengusaha UMKM ternyata berpengaruh positif terhadap tingkat pemahaman pengusaha terkait SAK-ETAP sebagai dasar dalam praktik akuntansi pada UMKM saat ini. Untuk itu, dapat dinyatakan bahwa tidak diterapkannya praktik akuntansi secara optimal pada sebagian besar UMKM selama ini dikarenakan pengetahuan akuntansi baik pemilik maupun staf keuangan/akuntansi UMKM saat ini masih belum memadai.

Para pelaku UMKM merasa terlalu direpotkan dengan penyelenggaraan catatan akuntansi tersebut dan menganggap bahwa yang penting adalah mereka mendapatkan laba tanpa direpoti dengan penyelenggaraan akuntansi (Pinasti, 2001). 
Hal terpenting bagi UMKM adalah cara menghasilkan laba sebanyak mungkin dari usaha yang dijalankan tanpa direpoti dengan masalah pembukuan/akuntansi (Idrus, 2000).

Pelaku UMKM menganggap bahwa manfaat atas informasi akuntansi yang dihasilkan lebih kecil dibandingkan biaya yang harus mereka korbankan ketika mereka menyelenggarakan praktik akuntansi secara tepat.

Wahdini \& Suhairi (2006) menyatakan bahwa salah satu faktor yang diduga sebagai penyebab rendahnya tingkat penyusunan laporan keuangan pada UKM di Indonesia adalah adanya kewajiban UKM menggunakan Standar Akuntansi Keuangan (SAK) yang sama dengan usaha besar. Kewajiban menggunakan standar pengukuran yang sama, telah memberatkan UKM dalam penyusunan laporan keuangan, karena untuk menghasilkan informasi akuntansi (baca laporan keuangan), UKM membutuhkan biaya yang lebih besar dibandingkan manfaat yang dapat diperoleh dari adanya informasi akuntansi tersebut. Untuk itu, dapat dinyatakan bahwa tidak diterapkannya praktik akuntansi secara optimal pada sebagian besar UMKM selama ini dikarenakan manfaat yang diperoleh atas praktik akuntansi lebih kecil daripada biaya yang harus dikeluarkan.

Pinasti (2001) menemukan bahwa ukuran usaha merupakan faktor yang sulit dipisahkan dengan lingkungan pengusaha UMKM. Ukuran usaha dapat mempengaruhi pemikiran pengusaha terkait dengan kompleksitas dan semakin tingginya tingkat transaksi perusahaan sehingga diharapkan dengan makin besarnya ukuran usaha maka dapat mendorong sesorang untuk berpikir dan belajar terkait solusi untuk menghadapinya. Berkaitan ukuran UMKM dan hubungannya dengan praktik akuntansi pada UMKM,

hasil penelitian Rudiantoro \& Siregar (2011) menunjukkan bahwa ukuran usaha berpengaruh positif terhadap Persepsi Pengusaha UMKM atas pentingnya pembukuan dan pelaporan keuangan bagi usahanya, sehingga di saat semakin tumbuh dan besarnya usaha UMKM, maka pengusaha mulai memandang penting kebutuhan laporan keuangan tersebut. Semakin besar usaha maka pemiliknya mulai memikirkan pentingnya suatu pembukuan dan pelaporan keuangan untuk membantu dalam pengelolaan aset dan penilaian kinerja keuangannya. Untuk itu, dapat dinyatakan bahwa tidak diterapkannya praktik akuntansi secara optimal pada sebagian besar UMKM selama ini dikarenakan jumlah UMKM di Indonesia masih didominasi oleh Usaha Mikro dan Kecil, yang mana pada kedua jenis kelompok usaha tersebut masih lebih banyak dikelola secara perseorangan dengan manajemen seadanya.

Atas dasar pemaparan diatas menunjukkan bahwa fenomena tidak terselenggarakannya praktik akuntansi secara optimal dan tidak termanfaatkannya informasi akuntansi pada UMKM selama ini bukanlah semata-mata merupakan kesalahan ataupun kekurangan para pelaku UMKM, tetapi juga dikarenakan belum optimalnya peran serta pemerintah dan masyarakat dalam mendorong praktik akuntansi di UMKM.

Informasi akuntansi mempunyai peran penting untuk mencapai keberhasilan usaha, termasuk bagi usaha kecil (Megginson et al., 2000 dalam Pinasti, 2007). Informasi akuntansi dapat menjadi dasar yang andal bagi pengambilan keputusan dalam pengelolaan usaha kecil dan menengah, antara lain untuk keputusan penetapan harga, pengembangan pasar, termasuk untuk keputusan investasi (Suhairi, dkk., 2004). Namun, dalam kenyataannya, pada umumnya pengusaha kecil tidak menyelenggarakan dan menggunakan informasi akuntansi dalam pengelolaan usahanya (Pinasti, 2001), sehingga kualitas laporan keuangan pada UMKM masih rendah (Rudiantoro \& Siregar, 2011) dan praktek akuntansi, khususnya akuntansi keuangan pada UMKM di Indonesia memiliki banyak kelemahan (Suhairi, dkk, 2004).

Tidak adanya penyelenggaraan dan penggunaan informasi akuntansi dalam kebanyakan pengelolaan usaha kecil ditentukan oleh persepsi pengusaha kecil atas informasi akuntansi.Bagi sebagian besar UMKM, tidak pentingnya pemanfaatan informasi akuntansi karena mereka merasa tidak membutuhkan informasi akuntansi (Hariyanto, 1999) dan memandang akuntansi merupakan sesuatu yang sangat sulit untuk dijangkau (Idrus, 2000). Pengusaha kecil telah merasakan manfaat atas keberadaan informasi akuntansi maka mereka akan menganggap 
bahwa informasi akuntansi penting bagi mereka, namun sebaliknya selama pengusaha kecil tersebut tidak pernah menggunakan informasi akuntansi maka informasi akuntansi dianggap sesuatu yang tidak penting.

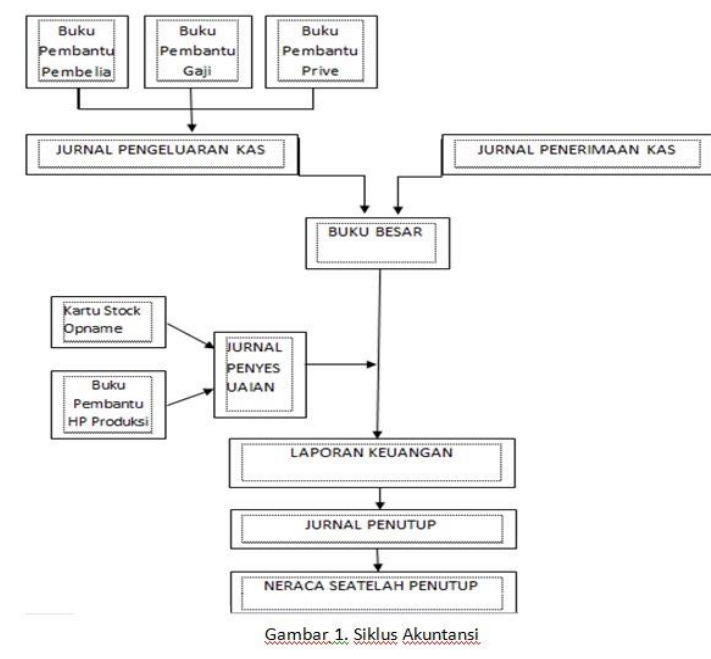

Akuntansi tidak hanya laporan keuangan saja yang dibutuhkan tapi juga bukti-bukti pendukung untuk menunjang pengendalian kas pada suatu entitas. Bukti pendukung ini berupa formulir-formulir dan dokumen pendukung yang akan diisi oleh suatu entitas dalam setiap transaksi yang terjadi pada entitas tersebut. formulir adalan secarik kertas yang memiliki ruang untuk diisi. Manfaat dari formulir yaitu menetapkan tanggung jawab timbulnya transaksi bisnis perusahaan, merekam data transaksi bisnis perusahaa, mengurangi kemungkinan kesalahan dengan cara menyatakan suatu kejadian dalam bentuk tulisan, menyampaikan informasi pokok dari orang satu ke orang lain di dalam organisasi yang sama atau ke organisasi lain.

Namun, pengelolaan keuangan ini juga harus mempertimbangkan sumber daya yang terlibat. Untuk usaha kecil , umumnya, berpendidikan dasar dan menengah. Maka untuk menyusun laporan keuangan pada usaha industri rumahan hanya diperlukan pencatatan sederhana serta dokumen pendukung yang digunakan untuk pencatatan transaksi keuangan. Catatan yang dibuatkan berupa buku kas, jurnal penerimaan kas, jurnal pengeluaran kas, buku pembantu Utang dan Piutang dan Harga Pokok. Proses pencatatan tersebut dilakukan dengan cara mencatat transaksi ke dalam buku kas setiap hari, pindahkan ke

jurnal penerimaan dan pengeluaran kas, Biaya produksi diposting ke buku besar, catat buku pembantu harga pokok, buat dokumen laporan perhitungan fisik persediaan dan perhitungan fisik perlengkapan, membuat jurnal penyesuaian, membuat neraca lajur, dan membuat neraca saldo per tanggal akhir periode pencatatan. Proses pencatatan tersebut akan menghasilkan laporan harga pokok produksi dan laporan keuangan yang terdiri dari laporan laba-rugi, laporan perubahan ekuitas, laporan posisi keuangan, dan laporan arus kas.

\section{Kondisi Mitra}

Mitra terdiri dari 2 pembuat sala lauak di ulakan pariaman yang menjualkan langsung produk mereka di depan rumah mereka berupa warung kecil yang terdiri dari etalase dan meja produksi. Mitra pertama bernama Indrawati/ Kitik (Sala Lauak Kitik), 43 tahun, seorang janda dengan 5 anak (1 laki-laki dan 4 perempuan) yang masih sekolah. Memulai usaha sejak dari 10 tahun yang lalu. Selain sala lauak, Kitik juga memproduksi rakik ikan (udang, bada, kepiting). Setiap hari Kitik bisa produknya paling banyak Rp. 50.000 penjualan. Namun di hari Libur bisa mencapai Rp.80.000 sampai Rp. 100.000,-Puncak pendapatan diterima saat Ulakan di kunjungi dalam rangka basyafa.

Mitra ke dua adalah Helmi (Sala Lauak Helmi), 30 tahun, Ibu dari 2 orang anak yang meneruskan penjualan sala Lauak dari ibunya. Penghasilan mitra Helmi kurang lebih sama dengan Kitik. Panen penghasilan hanya sekali setahun yaitu saat basyafa. Selain itu, penghasilan biasa saja dalam artian sekedar pelepas makan.

Persoalan yang sangat penting dan harus dipikirkan adalah bagaimana menyajikan makanan khas sedemikian baik dan menarik, sehingga akan menarik orang untuk membelinya.Hal itu harus didukung pula oleh inovasi dan peningkatan kualitas serta kreativitas masyarakat dalam memproduksinya. Usaha makanan tradisonal di kota Pariaman sangat memungkinkan untuk menjadi kegiatan bisnis, karena didukung dengan beberapa faktor seperti potensi bahan baku yang cukup tersedia yaitu ikan, kelapa, ternak dan tenaga kerja.

\section{Potensi dan Peluang Mitra}


Kitik dan Helmi sama sama mitra yang memiliki tempat (stall) usaha milik sendiri. Mereka berjualan di tempat khusus yang menjadi bagian dari rumah mereka. Jadi tidak ada kekhawatiran akan digusur atau dipindahkan. Berbeda dengan sebagian besar pedagang sala lauak di wilayah Ulakan, yang menggunakan fasilitas umum (pinggir dan badan jalan). Yang selalu khawatir tergusur dan kerepotan setiap hujan dating karena harus menyelamatkan dagangan mereka.

Produk yang dijual mitra merupakan makanan tradisional khas wilayah pariaman yang bisa di jadikan oleh-oleh dan dikembangkan untuk menjadi produk makanan olahan berbasis beras dan ikan.

Mitra juga terbuka terhadap masukan dan perubahan. Mitra mau memperbaiki dan menerima saran yang diberikan. Meskipun mitra sendiri berpendidikan menenggah pertama, Namun anak kandung mitra Kitik berpendidikan sekolah meneggah atas jurusan IPS dan juga mempelajari akuntansi di sekolahnya sehingga proses transfer ilmu relative lebih mudah.

Mitra Helmi sendiri menyanggupi melakukan perbaikan manajemen dan pembukuan nya dan bersedia bekerja sama.

\section{Permasalahan mitra}

Mitra memulai produksinya secara sederhana. Produk sala dibuat harian dengan jumlah terbatas karena sedikitnya penjualan harian. Sementara Produk variasi rakik yang merupakan olahan ikan lainnya dibuat sekali 2 atau 3 hari tergantung lama habisnya produk itu terjual.

Selain itu peralatan produksi sangat minim dan jauh dari higienis. Produk digoreng di kuali yang dasarnya sudah menghitam karena lama terpakai dan jarang dibersihkan. Minyaknya pun adalah minyak goreng yang dipakai berulang, sudah menghitam dan dipakai untuk semua kebutuhan penggorengan termasuk untuk salad an rakik.

Penyajian produk dilakukan seadanya. Produk diletakkan di piring, lalu ditinggikan di atas kaleng, kemudian disusun di atas meja atau di etalase setengah terbuka tanpa di tutupi apa-apa. Kalaupun ada hama berupa lalat atau debu, mitra hanya bisa menghalaunya dengan kibasan kertas. Makanan yang di produksi dibiarkan saja terbuka sampai ada pembeli. Kalo ada yang berkenan membeli, Mitra akan menggulang mengorengnya selayang agar menjadi garing.

Mitra lalu membungkus salad an rakik nya di kresek yang telah dialasi Koran. Tujuan pemakaian Koran adalah agar minyaknya berkurang. Kresek yang dipakai tidak selalu kresek bening atau putih tapi juga hitam, tergantung persediaan.

Karena penjualan harian tidak terlalu banyak menurut ukuran mereka, maka pencatatan jarang sekali dilakukan. Alasannya karena mereka sudah hapal berapa pengeluaran dan penerimaan harian.

\section{METODE PELAKSANAAN}

Metode pelaksanaan kegiatan adalah dengan 1) Membuatkan perencanaan bisnis dan manajemen usaha dengan perbaikan pencatatan keuangan/pembukuan; 2) Meningkatkan kemampuan mitra dalam memproduksi melalui alih pengetahuan mitra dalam pengolahan makanan tradisional (Sala Lauak) yang higienis, penggunaan peralatan proses produksi yang mendukung (penggorengan dan pengemasan); 3) Meningkatkan Nilai tambah makanan tradisional sala lauak dan pendapatan mitra melalui diversifikasi produk; 4) Melakukan Transfer pengetahuan dalam pelayanan dan penjualan melalui penataan ulang (re lay-out) tempat penjualan dan metode penjualan; 5) Membantu dan mendampingi mitra memperoleh legalitas produksi (dinkes pirt) dengan transfer pengetahuan tentang keamanan pangan dan sanitasi 6) Menemukan model pelatihan yang tepat untuk mitra antara diskusi, sharing, contoh langsung: 7) Menemukan Model Pembinaan dan pemdampingan yang tepat untuk mencapai tujuan dari kegiatan ini.

Untuk itu perlu dibuat model pembukuan sederhana bagi UMKM, khususnya home industry Sala Lauak yang banyak terdapat di daerah Ulakan, Kabupaten Padang Pariaman, Sumatera Barat. Artikel ini akan membahas tentang model catatan dan dokumen yang digunakan serta dapat diaplikasikan dalam kegiatan usaha Sala Lauak

\section{Alat dan bahan}

Alat dan bahan yang digunakan adalah berupa : Modul yang terdiri dari modul 
Pembukuan sederhana, Modul Keamanan pangan, Modul Penataan Layout usaha.

Perbaikan Re Lay Out Usaha yaitu dengan perbaikan tata letak (dengan menata ulang kursi meja dan tempat produksi berupa tempat penggorengan, Perbaikan loteng, Perbaikan dinding warung dengan mencat ulang dan menempelkannya dengan merk dan hiasan sehingga lebih attaraktif dan menarik. Perbaikan Instalasi Listrik sehingga warung menjadi lebih terang, dan aman. Pengaturan tampilan produk, dalam etalase sehingga lebih higienis dan menarik

Keterampilan produksi yang dimiliki oleh pedagang menunjang terhadap proses produksi karena dagangan mereka sudah mendarah daging dengan mereka, dengan proses produksi yang lebih canggih, ditambah adanya diversifikasi pangan, baik berupa perubahan bahan dan resep, pedagang dipercaya bisa memiliki produksi yang lebih baik. Alat dan bahan produksi menjadi lebih baik.

Untuk perbaikan sanitasi dan keamanan pangan melakukan diantaranya perbaikan alat produksi, perbaikan proses produksi dan perbaikan kemasan.

Perbaikan layout usaha dan pengetahuan tentang keamanan pangan disertai peralatan produksi yang lebih baik ,dipercaya dapat meningkatkan pendapatan pedagang. Karena produk menjadi lebih higienis, dan memilik daya jual yang lebih baik.

\section{HASIL DAN PEMBAHASAN}

Hasil dari kegiatan ini adalah : 1) alih pengetahuan tentang perencanaan bisnis dan manajemen usaha dengan perbaikan pencatatan keuangan/ pembukuan melalui perencanaan keuangan, pendokumentasian transaksi dan pembukuan sederhana; 2) alih pengetahuan mitra dalam pengolahan makanan tradisional sala lauak dengan teknik goreng yang higienis, penggunaan peralatan proses produksi yang mendukung (penggorengan dan pengemas); 3) alih pengetahuan melalui diversifikasi produk melalui formula yang di perbaiki (pengembangan resep baru) dan tambahan variasi makanan yang dijual ; 4) alih pengetahuan dalam layanan penjualan melalui penataan ulang (re lay-out) tempat penjualan dengan perbaikan display makanan yang menjadikan pembeli nyaman dalam berbelanja serta perbaikan metode penjualan; 5) pendampingan mitra dalam memperoleh legalitas produksi (dinkes pirt) melalui transfer pengetahuan dan perbaikan sarana dan prasarana : 6) model pelatihan yang tepat untuk mitra adalah sharing dan diskusi serta praktek langsung: 7) model pembinaan dan pemdampingan yang tepat untuk mencapai tujuan dari kegiatan ini adalah berbasis pemberdayaan sumber daya mitra dan masyarakat sehingga diharapkan untuk kedepannya mitra bisa menjadi role model pengembangan usaha home industry sala lauak di wilayah ulakan yang terkonsep, higienis dan mempunyai daya saing sehingga dapat meningkatkan pendapatan masyarakat di wilayah Ulakan Pariaman.

\section{Partisipasi Mitra :}

Mitra dalam hal ini berpartisipasi dalam mendukung pelaksanaan kegiatan pelatihan dan perbaikan. adapun partisipasi mitra dapat di jelaskan sebagai berikut:

1. mendukung pelaksanaan pembukuan sederhana yang dikembangkan tim, dengan menyediakan data dan informasi yang dibutuhkan terkait persoalan keuangan dan transaksi yang mereka hadapi. Serta kesediaan untuk melakukan proses pembukuan sesuai yang telah di ajarkan dalam pelatihan secara kontinue sehingga membawa perubahan dalam manajemen dan keuangan

2. Mendukung dan melaksanakan pembinaan usaha melalui perbaikan lay out usaha (warung) dan secara konsisten melaksanakan penerapan keamanan pangan dalam produksi dan penjualan baik pengolahan , penyajian dan berupa kemasan.

3. Merawat dan menjaga peralatan yang di berikan berupa alat pengemas dan alat untuk pengering makanan sehingga dapat di manfaatkan dengan baik.

4. Dengan di berikannya merk pada usaha dan perbaikan pada stall( warung) mitra di minta untuk konsisten menjaga kualitas produk sesuai dengan slogan merk mereka yang sehat dan higienis.

5. Mitra didorong untuk mulai membuka diri untuk melakukan promosi lebih intensif dengan mengembangkan media promosi seperti brosur yang disebarkan kepada target pelanggan 
seperti instansi, sekolah atau melalui pelanggan yang telah ada. Karena Mitra untuk pemasaran produk warung dilengkapi dengan merek yang cukup dan kemasan yang di lebih baik

6. Mitra di arahkan memiliki sistem pengelolaan keuangan yang standar sehingga bisa dijadikan dasar pendanaan kepada pihak lain.

\section{TEMUAN}

Adapun temuan dan analisa terhadap temuan serta solusinya adalah sebagai berikut:

\begin{tabular}{|c|c|}
\hline Temuan & Analisa dan solusi \\
\hline $\begin{array}{l}\text { Untuk materi pelatihan } \\
\text { berupa materi } \\
\text { pembukuan } \\
\text { keamanan pangan, } \\
\text { Mitra kesulitan dalam } \\
\text { memahami materi yang } \\
\text { berat sehingga } \\
\text { membutuhkan waktu } \\
\text { yang lama untuk } \\
\text { menjelaskan } \\
\text { memberikan } \\
\text { nyata/ riel. }\end{array}$ & $\begin{array}{l}\text { Metode yang tepat } \\
\text { adalah diskusi dan } \\
\text { pemberian contoh. } \\
\text { Mitra benar benar di } \\
\text { guide dibimbing untuk } \\
\text { memahami materi step } \\
\text { by step (perlangkah) dan } \\
\text { diterangkan secara jelas } \\
\text { berikut contoh kejadian, } \\
\text { solusi dan } \\
\text { penyelesaiannya. }\end{array}$ \\
\hline $\begin{array}{l}\text { Untuk diversifikasi } \\
\text { pangan, mitra di ajarkan } \\
\text { resep baru baik berupa } \\
\text { pengembangan } \\
\text { resep lama maupun } \\
\text { resep baru. Namun } \\
\text { dengan penerapan cara } \\
\text { produksi yang lebih } \\
\text { sehat dan higienis }\end{array}$ & 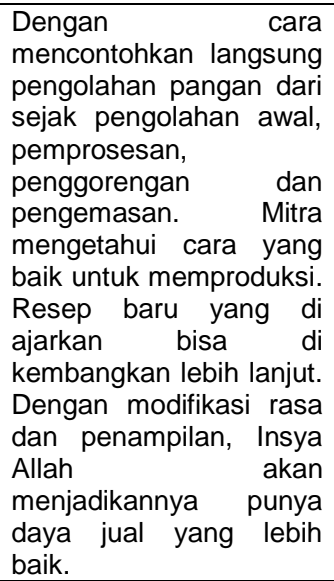 \\
\hline 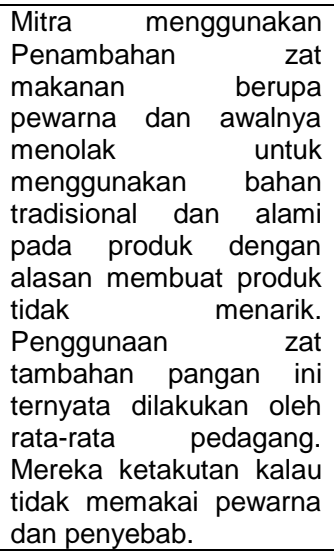 & $\begin{array}{lr}\text { Praktek langsung } \\
\text { dengan } & \text { mitra } \\
\text { membuktikan } & \text { kalau } \\
\text { anggapan bahan } & \text { alami } \\
\text { membuat } & \text { tidak } \\
\text { menariknya tampilan } & \text { tidak } \\
\text { produk adalah } \text { tuk } \\
\text { benar. Sehingga mitra di } \\
\text { apporach di bujuk dan } \\
\text { diyakinkan untuk selalu } \\
\text { menggunakan bahan } \\
\text { alami. } \\
\text { praktek makanan sehat } \\
\text { dan aman di harapkan } \\
\text { dapat menjadi role } \\
\text { model bagi pedagang } \\
\text { lain di wilayah ulakan. }\end{array}$ \\
\hline
\end{tabular}

\begin{tabular}{|l|l|}
\hline Temuan & Analisa dan solusi \\
\hline Mitra butuh didampingi & Bnetuk pendampingan \\
dalam penerapan praktik & adalah kunjungan dan \\
manajemen usaha dan & evaluasi recara \\
keuangan karena & bertahap. Sambil terus \\
lemahnya basic / dasar & diperbaiki dan dikuatkan \\
mereka terhadap konten & praktek sehat (baik \\
isi materi. & secara keuangan \\
& maupun manajemen \\
& usaha) yang dilakukan \\
& mitra \\
\hline
\end{tabular}

\section{KESIMPULAN DAN SARAN}

Mitra membutuhkan alih pengetahuan tentang perencanaan bisnis dan manajemen usaha untuk keberlanjutan usaha mereka yaitu dengan pendokumentasian transaksi dan pembukuan sederhana. Mitra dalam pengolahan makanan tradisional sala lauak perlu di latih lagi untuk memproses secara aman dan sehat yaitu dengan teknik goreng yang higienis, penggunaan peralatan proses produksi yang mendukung (penggorengan dan pengemas); Mitra perlu diyakinakan dengan diversifikasi produk dan tambahan variasi makanan yang dijual, Mitra perlu dilatih untuk memperbaiki pelayanan penjualan melalui perbaikan display makanan yang menjadikan pembeli nyaman dalam berbelanja serta perbaikan metode penjualan; . Model pelatihan yang tepat untuk mitra adalah sharing dan diskusi serta praktek langsung: Model pembinaan dan pendampingan yang tepat untuk mencapai tujuan dari kegiatan ini adalah berbasis pemberdayaan sumber daya mitra dan masyarakat sehingga diharapkan untuk kedepannya mitra bisa menjadi role model pengembangan usaha home industry sala lauak di wilayah ulakan yang terkonsep, higienis dan mempunyai daya saing sehingga dapat meningkatkan pendapatan masyarakat di wilayah Ulakan Pariaman.

\section{DAFTAR PUSTAKA}

Direktorat Statistik Ekonomi dan Moneter Bank Indonesia. 2010. Metadata Kredit Usaha Mikro, Kecil dan Menengah (UMKM). Akses tanggal $16 \quad$ April 2015. http://www.bi.go.id/web/id/ Statistik/Metadata/SEKDA/.

Hariyanto, E. 1999.Analisis Kebutuhan

18 Jurnal Akuntansi \& Manajemen Vol 10 No. 2 Desember 2015. ISSN 1858-3687 hal 11-19 
Model Pelatihan, Pembinaan dan Pendampingan Usaha Sala Lauak di Ulakan Pariaman

Informasi Akuntansi bagi Usaha Perdagangan Eceran(Retail) di Kotatip Purwokerto.Jurnal Ekonomi Bisnis dan Akuntansi. No. 1/Vol.1/September.

Idrus. 2000. Akuntansi dan Pengusaha Kecil. Akuntansi.Edisi 07/Maret/Th. VII.

Kementerian Negara Koperasi \& UKM RI. 2011. Perkembangan Data Usaha Mikro, Kecil,Menengah (UMKM) Dan Usaha Besar (UB) Tahun 2006 2010.

http://www.depkop.go.id/index.php?o ption=com_phocadownload\&view=fil e\&id=257:d ata-usaha-mikro-

Pinasti, Margani. 2001. Penggunaan Informasi Akuntansi dalam

kecil-menengah-umkm-danusaha-besar-ub-tahun-20062010\&ltemid=93 .Akses tanggal 16 April 2015

Rudiantoro, Rizki \& Siregar, Sylvia Veronica. 2011. Kualitas Laporan Keuangan UMKM Serta Prospek Implementasi SAK ETAP. Makalah Simposium Nasional Akuntansi XIV. Aceh

Suhairi, Sofri Yahya \& Hasnah Haron. 2004. Pengaruh Pengetahuan Akuntansi Dan Kepribadian Wirausaha Terhadap Penggunaan Informasi Akuntansi Dalam Pengambilan Keputusan Investasi. Makalah Simposium Nasional Akuntansi VII.Denpasar.

Wahdini dan Suhairi.2006. Persepsi Akuntan Terhadap Overload Standar Akuntansi Keuangan (SAK) Bagi Usaha Kecil Dan Menengah.Makalah Simposium Nasional Akuntansi IX. Padang.

Supardi,.2005. Keracunan Makanan. Makalah Seminar : Keamanan Pangan Untuk Menunjang Bisni Boga dan Pariwisata.
Pengelolaan Usaha Para

Pedagang Kecil di Pasar

Tradisional Kabupaten Banyumas. Jurnal Ekonomi, Bisnis dan Akuntansi No. 1/Vol. 3/Mei.

$2007 . \quad$ Pengaruh

Penyelenggaraan dan

Penggunaan Informasi Akuntansi

Terhadap Persepsi Pengusaha

Kecil atas Informasi Akuntansi:

Suatu Riset Eksperimen. Jurnal Riset Akuntansi Indonesia.Vol. 10 (3).Hal.321-331.

Romney, Marshal B. \& Steinbart, Paul John. 2005. Accounting Information Systems. Edisi kesembilan.Terjemahan. Salemba Empat, Jakarta. 